\title{
Bőgel György*
}

\section{Tegnap, ma, holnap: a vállalati tevékenységek kiszervezésének trendjei}

\begin{abstract}
A tevékenységek kiszervezése, illetve annak nemzetközi változata, az úgynevezett offshore outsourcing napjaink gazdaságának egyik legfontosabb jelensége. A termelés kihelyezése olcsó országokba már évtizedekkel ezelött megindult. Az infokommunikácós technológia fejlődésének köszönhetően a múlt század kilencvenes éveiben az egyéb, többnyire szolgáltatás jellegü vállalati tevékenységek is sorra kerültek. $A$ near-shoring és az off-shoring hatalmas, dinamikusan fejlődő iparággá vált, ami különleges lehetőségeket biztosít számos feltörekvő országnak. A szektorban élénk verseny bontakozott ki, aminek részese hazánk is. Ebben a küzdelemben sajátos ország- és vállalati stratégiák figyelhetők meg. A fejlődés számos gazdasági, politikai és társadalmi problémát vet fel, amelyekre megoldást kell keresniük mindazoknak, akik élni kívánnak a lehetőségekkel.
\end{abstract}

Journal of Economic Literature (JEL) kód: L24.

Kulcsszavak: kiszervezés, outsourcing, vállalati szervezet, szolgáltatások, $K+F$, globalizáció, munkanélküliség, India, Kína, információs technológia, internet, versenyképesség

Tíz-tizenöt év a történelemben nem nagy idő, mégis elég lehet ahhoz, hogy egyes területeken fontos változások menjenek végbe. Ezek közé tartozik a vállalati tevékenységek kiszervezése, azaz egyes, korábban vállalaton belül végzett munkák külső szolgáltatóknak, szállítóknak történő átadása, közismert nevén az outsourcing is.

A „csináljuk vagy vegyük” kérdése egyidős a vállalatokkal. Egy vállalat, illetve bármilyen autonóm szervezet eldöntheti, hogy milyen, a müködéséhez, fennmaradásához szükséges tevékenységeket kíván saját határain belül, saját szervezeti rendjébe, hierarchiájába illesztve végezni, illetve melyeket kíván más szervezetekre bízni. Piacgazdaságban ez a döntés elvileg racionális megfontolások, az előnyök és hátrányok gondos mérlegelése alapján születik meg: a döntéshozók szembeállítják egymással a különböző megoldások várható költségeit és hasznait, elemzik a kockázati tényezőket, a személyi, technikai és egyéb feltételeket, majd leteszik a voksot valamelyik megoldás mellett.

Mivel ezek nem állandó tényezők, a döntés idővel meg is változhat: gyakran előfordul, hogy korábban kihelyezett tevékenységeket „visszaszerveznek”, és megfordítva. A sok egyedi megoldás mellett vannak általános, hosszabb távú, tartósabb trendek is. Ebben a

\footnotetext{
* A szerző a CEU Business School tanári karának tagja, a Debreceni Egyetem Közgazdaságtudományi Karának docense. E-mail: bogelgy@ceubusiness.com
} 
cikkben ezek közül szeretnék foglalkozni néhánnyal, jelesül azokkal, amelyek a nemzetközi munkamegosztás átalakulásával kapcsolatosak.

A nemzetközi színtérre való kitekintés témánk esetében elengedhetetlen. A közelmúlt és a jelen legfontosabb trendje a kiszervezés nemzetközivé válása, globalizálódása. A világ vezető vállalatainak nagy többsége kihasználja a „global sourcing” adta lehetőségeket, de a kis- és középvállalatok esetében is egyre gyakoribb egyes tevékenységek szolgáltatásként való megvásárlása olcsó országokból. Mivel a lehetőségek és megoldások köre folyamatosan bővül, a döntés, a sokféle tényező számbavétele egyre bonyolultabb. Az outsourcing-üzletbe újabb és újabb országok kapcsolódnak be, számos esetben állami gazdaságpolitikai döntés alapján, a központi gazdaságirányítás által megtervezett és támogatott programok keretében.

Miközben szinte minden elörejelzés lendületes és hosszú ideig tartó piaci növekedést jelez, a kiszervezett, illetve kiszervezhető tevékenységekért folytatott verseny egyre élesebb.

Ennek a versenynek hazánk is részese. Magyarország számára a globalizálódó outsourcing-trend kiváló lehetőségeket jelent, nem csoda tehát, hogy rendszeresen megjelenik a stratégiai elképzelésekben. Képességeink e téren csak a nemzetközi versenymezőny ismeretében értékelhetők, reális, végrehajtható elképzelések csak a jelen és a jövő feltételrendszeréhez igazodva születhetnek meg. Magyarországra már számos vállalat helyezte ki egyes tevékenységeit, folyamatait, funkcióit. A média rendszeresen beszámol folyamatban lévő tárgyalásokról. E jelenségekből arra következtethetünk, hogy hazánk vonzó ország, amely másokkal szemben fontos elönyöket tud felmutatni. A versenymezőny azonban folyamatosan változik, a meglévő előnyöket állandó veszély fenyegeti.

A következőkben a tevékenységek kiszervezésének nemzetközivé válásáról, globalizálódásáról, a jelenlegi versenymezőnyről és a jövő várható fejleményeiről, nyitott kérdéseiről igyekszünk képet adni. Az első részben a kezdeti időszakkal foglalkozunk, a másodikban a közelmúlt és a jelen folyamataival, a harmadikban pedig a további fejlődés lehetséges irányait és nyitott kérdéseit foglaljuk össze.

A cikkben szereplő, az outsourcing piac méreteire, növekedésére vonatkozó adatokat fenntartásokkal kell kezelni. Az általános trendek eléggé egyértelműek, de a konkrét számok tekintetében már jelentés eltérések mutatkoznak. Gyakori eset, hogy különböző, egyébként jó nevü piacelemző cégek módszertani és egyéb okokból kifolyólag más-más számokkal rukkolnak elö. Különösen sok probléma van az export-import adatokkal, mivel az egyes országok statisztikai rendszerei nem egyformák, ráadásul a szolgáltatások (pl. szoftverfejlesztés) forgalmát nehezebb meghatározni, mint a fizikai formában megjelenő árucikkekét. Előfordulhat például, hogy X ország azt jelzi, hogy adott értékű szolgáltatást exportál Y-ba, de ez nem egyezik Y ország import statisztikáival. A „foreign direct investment” mutatókban is jelentős torzulások lehetnek. Köztudott például, hogy mivel Kína kedvezményekkel ösztönzi a betelepülő tőkét, a kínai saját befektetések egy része is kerülőutakon, más országokból érkezve bukkan fel. Az FDI egy része tehát valójában hazai befektetés.

A számok, statisztikák értelmezése azért is nehéz, mert a gyakorlatban a munkahelyek, a feladatok, a folyamatok vándorlása többféle formában jelentkezik. Kiszervezésnek általában azt nevezzük, amikor egy vállalat vagy bármilyen más szervezet egyes, korábban házon belül végzett tevékenységeit átadja valaki másnak. Sokszor előfordul azonban az is, hogy valamit meg sem szerveznek házon belül, hiszen a megfelelő szolgáltató rendelkezésre áll. Ebben a cikkben mindkét megoldást „outsourcingnak” tekintjük, de a különböző felmé- 
rések és statisztikák készítői nem feltétlenül gondolkodnak így, és sajnos gyakran a pontos definíció és módszertan leírását is elmulasztják.

\section{Tegnap}

Menjünk most vissza az időben tízegynehány évet, és nyissunk ki néhány olyan szakkönyvet, amelyek a nemzetközi üzlettel, az „international business”-szel foglalkoznak (lásd pl. Daniels-Radebaugh 1993). Tipikus esetben hogyan tárgyalják ezek a könyvek nemzetközi viszonylatban a kiszervezés, az outsourcing témakörét? Nem a legfontosabb témák (export, külföldi beruházások, nemzetközi pénzügyi rendszer) között, de figyelemre méltó újdonságként, erősödő trendként. A növekvő érdeklődés könnyen magyarázható. A nyolcvanas évek vége, a kilencvenes évek eleje fontos változásokat hozott a világpolitikában és -gazdaságban: leomlott a berlini fal, szétesett a Szovjetunió és Jugoszlávia, a volt szocialista tábor országaiban beindult a rendszerváltás és a privatizáció, a két Németország egyesült, egyes régiókban szabadabbá vált a nemzetközi kereskedelem, és így tovább.

Egy másik jelenség, amit megfigyelhetünk: ha ezek a könyvek megemlítik a tevékenységek kiszervezését, alapvetően termelési tevékenységekre gondolnak. Azt mutatják be, miként dönt egyre több vállalat úgy, hogy termelési folyamatainak egy részét (pl. alkatrészvagy részegység-gyártás, összeszerelés) külföldre telepíti. A „global sourcing” már ismert fogalom: azt fejezi ki, hogy forrásként elvileg az egész világ számításba jöhet: a döntéshozónak sokféle lehetőség közül lehet, illetve kell kiválasztania a legjobbat.

Kirajzolódik elöttünk a nemzetközi termelési rendszerrel, ellátási-logisztikai lánccal rendelkező vállalat képe, amely számos országban számos vállalkozóval dolgoztat.

Az egyik legjellegzetesebb példa az autógyártás lehet. A nyolcvanas évek végének egyik legnépszerübb autóját, a Ford Escortot Európában két helyen, az Egyesült Királyságban és Németországban szerelték össze, egyes alkatrészei, részegységei viszont a legkülönbözőbb országokban készültek: a különleges szelepek például az USA-ban, a rádió Kanadában, a hengerfejek Franciaországban, a festékek Hollandiában, a kipufogócsövek Svédországban, a fütőcsövek Ausztriában, az indító Japánban, a sebességmérő Svájcban.

A Ford Escort forrástérképén akkori szocialista ország nem szerepelt. A fejlődő világ azonban egyre inkább felkeltette a költségcsökkentési lehetőségek után szimatoló vállalatok érdeklődését. A bérek tekintetében valóban óriási különbségek mutatkoztak, ahogyan azt az 1. sz. táblázat jelzi.

\section{Tipikus órabérek különböző országokban 1988-ban}

\begin{tabular}{|l|l|}
\hline Ország & Órabér (\$) \\
\hline Mexikó & 0,88 \\
\hline Tajvan & 2,82 \\
\hline Dél-Korea & 2,5 \\
\hline Szingapúr & 2,67 \\
\hline Hong Kong & 2,40 \\
\hline Japán & 12,80 \\
\hline USA & 13,85 \\
\hline
\end{tabular}

Forrás: Daniels-Radebaugh 1993: 519. 
A költségelőnyök kihasználása érdekében a tevékenység-kiszervezés területén többféle sajátos megoldás született. Ezek egyike például az úgynevezett maquiladora-rendszer volt: Mexikóban különleges övezeteket hoztak létre, ezekbe az Egyesült Államok vállalatai vámmentesen alkatrészeket exportáltak, a helyi munkások végtermékekké szerelték össze őket, majd azokat kedvező vámok mellett visszaszállították az amerikai piacra vagy más célországokba. $\mathrm{Az}$ amerikaiak nyilván a munkaigényes termelési tevékenységeket igyekeztek kiszervezni, hiszen így tudtak hasznot húzni a bérek közötti különbségből. Nem akármekkora üzletről volt szó: a kilencvenes évek elején a mexikói maquiladora-iparban már mintegy félmillió ember dolgozott.

A termelés kiszervezésének, más országokba telepítésének a nyolcvanas évek elején az erős dollár is lökést adott, de a folyamat az évtized második felében sem állt le, pedig akkoriban gyengélkedett az amerikai valuta. Egy 1987 -es, 107 vezető amerikai vállalatra kiterjedő felmérés szerint a külföldi források aránya a cégek összes beszerzésében az 1980-as 8\%-ról 1985-86-ban 15\%-ra nőtt. A haladás persze nem volt problémamentes, a vállalatok sokat hibáztak, de amikor vissza akartak hozni külföldröl egyes tevékenységeket, többen azt tapasztalták, hogy a hazai szállítók felszívódtak - akkor tüntek el, amikor ügyfeleik korábban a külföldi beszerzés mellett döntöttek.

Érdemes azt is megvizsgálni, mi volt a helyzet akkoriban a mai kiszervezési akciók egyik legfontosabb célországában, Indiában. A hatalmas, milliárdos lakossággal rendelkező ország természetesen érdekelte az új piacokat kereső, saját országukon kívül is terjeszkedő nagyvállalatokat. India a kilencvenes évek elején még meglehetősen zárt, befelé forduló országnak számított, ahol gyanakodva fogadták az idegeneket, ami egyébként nem meglepő ilyen hosszú ideig tartó gyarmati alávetettség után. Bár a miniszterelnöki székben ugyanaz a Singh ült, aki ma is vezeti az országot, nem lehetett tudni, hogy az általa meghirdetett reformok mennyire változtatják meg a környezetet. Az üzleti iskolákban India viszonylatában általában a „PepsiCo in India” esettanulmányt vitatták meg, vagyis az volt a legérdekesebb kérdés, be tud-e törni az üdítöitalgyár a félszigetre.

Még bizonytalanabb volt a helyzet a Kinai Népköztársaság tekintetében: bár a fejlett nyugati országok politikai ellenségének számított, az ellenségeskedés a nyolcvanas évek során egyre inkább kölcsönös érdeklődéssé változott. Kínát érdekelte a piacgazdaság működése, a nemzetközi munkamegosztásba való élénkebb bekapcsolódás lehetősége, a nyugati exportpiac; a tőkés nagyvállalatok pedig látták, hogy egy politikailag „megszelídülo” Kína kiváló helyszín lenne gyártási tevékenységük kiszervezéséhez.

Hong Kong ekkoriban még önálló államnak számított, de közel volt már az idő, amikor a vonatkozó megállapodások szerint autonómiájáról le kellett mondania. Az 1989-ben a pekingi Tiananmen téren bekövetkezett mészárlás Hong Kongban is bizonytalanságot keltett, az ottani elitből sokan kivándoroltak, vagy a párnájuk alatt tartották a nyugati útlevelüket, hogy bármikor útnak indulhassanak, ha a helyzet a közelgő egyesítés miatt roszszabbra fordul. A bizonytalanság nagyjából két évig tartott, addig a befektetők és a potenciális kiszervezők jobbára „kivártak”, figyelték, milyen politika kerekedik felül.

Bár, mint látjuk, India és Kína ebben az időben még hátul kullogott a sorban, Ázsia más országai egyre élénkebben kapcsolódtak be a termelés kihelyezésének trendjébe. A nyugati elektronikai ipar vállalatai egyre-másra hozták létre termelö telepeiket a kontinensen, leginkább Tajvanon és Szingapúrban, de később egyéb államokban is, például Indonéziában és Thaiföldön. Fokozatosan nőtt az érdeklődés Dél-Amerika egyes országai iránt is. 
Az üzlet fejlődésén sokat lendített a nemzetközi kereskedelem fokozatos liberalizálódása, a kereskedelmet segítő megállapodások és intézmények létrejötte, a közlekedési és logisztikai rendszerek fejlődése - konkrétan a FedEx, a DHL, az UPS és más cégek tevékenységének állandó modernizálása és kiterjesztése. Maga a logisztika is kiszervezés tárgyává vált, hiszen az említett vállalatok számos partnerüktől gyakorlatilag az egész tevékenységet átvették. A pontos szállítás, a ,just in time” rendszer a nemzetközi outsourcingban is normává vált.

\section{Ma}

Haladjunk most tovább az időben, és vegyük szemügyre a kilencvenes évek elejétől napjainkig tartó időszakot. Azt tapasztaljuk, hogy a termelés olcsó országokba való kihelyezésének trendje nem fordult meg, sőt, tovább erősödött. A hazai és a külföldi költségek különbözőségéből fakadó előnyök kihasználása egyre inkább versenyképességi feltétellé vált. Jól mutatja ezt az Adidas példája. Ez a tradicionális német családi vállalat sokáig ellenállt a kiszervezés gondolatának, de amikor szembekerült a jóval fiatalabb, a termelést kezdettől fogva Ázsiába kihelyező, saját falain belül pedig a terméktervezésre és a marketingre koncentráló Nike-val és Reebokkal, végül beadta a derekát.

A kor menedzsment-irodalma azt az ideológiát erősítette, hogy a fejlett országok vállalatinak erősségeikre, a tudásigényes tevékenységekre kell koncentrálniuk, a szabványosított, leszabályozott tömegtermelést pedig át kell engedniük a szegényebb országoknak. Nézd át a vállalatod értékláncát - tanácsolta a szakirodalom -, az egyes láncszemekben hasonlítsd össze a teljesítményedet másokéval, és ha olyat találsz, ahol le vagy maradva, azt a tevékenységet engedd át a nálad jobbaknak, olcsóbbaknak. Az ideális vállalat „moduláris felépítésü”, az „alapvető képességeire” koncentrál. E gondolat jegyében döntött például úgy a svéd Ericsson, hogy „technológia-orientált hardvergyártóból” „tudásbázisú szoftvercéggé" alakul át.

A vezetési filozófia és módszertan fejlődése fontos szerepet játszott a folyamatban, mivel csökkentette a kiszervezési akciók bizonytalanságát, és így a kockázatát is. Az outsourcing tananyaggá vált az üzleti iskolákban, egy sor tanácsadó cég erre a feladatra szakosodott, vagy kiszervezési üzletágat is nyitott. A termelés egészének vagy részének kihelyezése rendes gyakorlattá vált.

Azonban nemcsak mennyiségi, hanem szerkezeti és minőségi változások is bekövetkeztek. Ezek közül az egyik leglátványosabb Kína rendkívüli megerősödése a termelési tevékenység átvételének területén. A politikai nyitás után a kilencvenes évek elejétől kezdődően, az úttörő Motorola és Nike példáját számtalan nyugati, legfőképpen amerikai vállalat követte. Kínában hatalmas tömegü, viszonylag jól képzett, fegyelmezett és olcsó munkaerőt találtak, és persze óriási potenciális felvevőpiacot. A motor valósággal berobbant. Míg a teljes nyolcvanas évtizedben a Kínába irányuló külföldi befektetések (FDI) összesen 20 milliárd dollárt tettek ki, addig a század végére ez a mutató már 200 milliárdra szaladt fel, a következő három évben pedig ez is megduplázódott (Targowski-Korth 2003). A külföldi forrásokhoz a kínaiak is csatlakoztak ${ }^{1}$, az olyan cégek, mint például a Haier, a Huawei vagy a Legend (Lenovo néven ők vették meg nemrég az IBM PC üzletágát) gyorsan bekerültek a legfelső vállalati súlycsoportba.

${ }^{1}$ Kína GDP-jében 40-45\% a befektetések aránya, ami nagyjából a duplája az USA és az EU megfelelö számainak. 
A termelés Kínába vándorlásának folyamata ma is változatlan lendülettel tart - a már említett olcsó és fegyelmezett munkaerő, a folyamatosan javuló infrastruktúra, a kedvező valutaárfolyamok, az adókönnyítések és a megszerezhető állami támogatások kombinációja olyan vonzeröt jelent, aminek nagyon nehéz ellenállni. Kína irányába a legnagyobb kiszervező ország Tajvan; az ország már korábban a világ számítástechnikai gyártóiparának fellegvárává vált (alaplapok, monitorok, laptopok stb. készítése), és most szinte az egész termelést áthelyezi a kontinensre, vagyis kiszervezési célpontból kiszervezővé vált.

A kilencvenes évtized az információs technológia és a távközlés robbanásszerű fejlödésének és terjedésének időszaka volt. A vállalatok rengeteg pénzt költöttek IT eszközökre, hardverre, szoftverre, rendszerintegrációs és egyéb szolgáltatásokra, kommunikációs rendszerek fejlesztésére. Megjelent az internet, összekapcsolódtak a cégen belüli informatikai szigetrendszerek, megkezdődött a vállalati folyamatok és tevékenységek technológiával erősen támogatott újraszervezése, szabványosodása. A technológiai fejlődés természetesen a vállalatok közötti kapcsolatokra is kihatott, hiszen idővel a vállalati informatikai rendszerek is összekapcsolhatókká váltak, az internetnek, a müholdaknak, a hatalmas tömegben lefektetett tengeralatti kábeleknek, a zuhanásszerüen csökkenő áraknak köszönhetően. Az egyre bonyolultabb (lásd például a Dell vagy a Nike globális folyamatait) termelési együttmüködéseket, beszállítói kapcsolatrendszereket informatikával támogatott, egyre nagyobb részben automatizált ellátási láncokká szervezték.

A termelés átszervezésén, a globális ellátási láncok kialakításán túl a technikai fejlődés más lehetőségeket is magával hozott. A közelmúlt és a jelen másik meghatározó trendje a szolgáltatások arányának lendületes növekedése a kiszervezett tevékenységek körében. Kibontakozását elsősorban az információs technológia és a távközlés fejlődése tette lehetővé, és az állandó, a verseny globalizálódása miatt egyre erősödő költségcsökkentési kényszer tette szükségessé.

Mivel a termelés kihelyezése számos iparágban már általános gyakorlattá vált, a vállalatoknak új kiadáscsökkentési és racionalizálási lehetőségek után kellett nézniük. Ki lehet helyezni olcsó országokba az ügyfélkapcsolatok kezelését, a könyvelést, a személyzeti adminisztrációt, az adatfeldolgozást és az egyéb szolgáltató jellegű tevékenységeket? - tették fel maguknak a kérdést. Mivel a válasz pozitív volt, megindult a termelésen kívüli vállalati funkciók olcsó országokba történő kihelyezése is. Ezeket a funkciókat racionalizálási, költségcsökkentési, szabványosítási akciók keretében sok vállalatnál már korábban összevonták, megosztott szolgáltató központokba ${ }^{2}$ szervezték, önálló költség- vagy nyereségközpontokká, sőt, jogi és pénzügyi önállósággal bíró cégekké alakították. Ezeket az egységeket viszonylag könnyű volt kiszervezni, eladni. A tanácsadói ipar természetesen lecsapott az új üzleti lehetőségekre, propagálni kezdte a kiszervezést, módszertanokat, mintákat dolgozott ki, ami újabb lendületet adott a folyamatnak. A feladatokat átvevő szolgáltatók kezdetben a megbízó cég telephelyén vagy annak közvetlen közelében működtek, a technikai fejlödésnek köszönhetően azonban a távolság jelentősége egyre kisebb lett, megindult tehát a szolgáltatások áramlása az olcsó országok felé.

Egyes vélemények szerint az internetnek és a széles sávú kapcsolatoknak köszönhetően elvileg minden kiszervezhetővé vált: az érintett részlegek között „nem kell kinyitni az ajtót", vagyis nincs szükség közvetlen fizikai kapcsolatra, személyes jelenlétre. Mindazonáltal a földrajzi távolság fontos szempont maradt, amit az is jelez, hogy a szakirodalom és a vál-

${ }^{2}$ Angolul: shared service center 
lalati zsargon megkülönbözteti egymástól a near-shoringot ${ }^{3}$ és az off-shoringot (a szavakat hol egybe-, hol kötőjellel írva): az előbbi egy közeli, például egy rövidebb autóúttal elérhető távolságra való kiszervezést jelent, az utóbbi pedig ennél távolabbit.

Pénzügyi szempontból az olcsó országokba való kiszervezést a látványos, többnyire 20 és 50\% között mozgó költségcsökkentési lehetőségek ösztönözték, amelyek leginkább a bérek közötti különbségekből adódtak, de más tényezők is szerepet játszottak a döntésekben, például a nagy tömegü és szakképzett munkaerőforrások elérése, az időzónák közötti különbség, vagy a fogadó országok által a betelepülő cégeknek nyújtott támogatás megszerzése.

A kiszervezett, illetve kiszervezhető vállalati tevékenységek és funkciók sorában az informatika állt az élen, ami nem csoda, hiszen a szoftverfejlesztési, tesztelési, rendszermenedzselési és egyéb hasonló tevékenységek nagy része valóban nem helyhez kötött, nem igényel közvetlen helyszíni jelenlétet. Az informatika után értelemszerűen azok az eljárások következtek, amelyek „anyagmentesek” és informatikával erősen támogatottak: ilyen például az adatfeldolgozás, a könyvelés és egy sor adminisztratív munka. Az angol nyelvü szakirodalom az informatikai tevékenységek kiszervezését „IT outsourcing”, az informatikával támogatott folyamatok átadását pedig „business process outsourcing” (röviden BPO) néven emlegeti (általában így találjuk meg őket a vállalati jelentésekben és a piacelemzői statisztikákban).

A sikeres offshore BPO-nak többféle feltétele van. Mindenfajta kiszervezésre igaz, hogy az ügyletből mindkét félnek megfelelő hasznot kell húznia, aminek számos forrása és megjelenési formája van, így például a nagy mennyiségből eredő gazdaságosság, az összpontosításból fakadó stratégiai előny, a költségstruktúra megváltozása, a korábbi hierarchikus kapcsolatok piacosítása és így tovább. Az átadás-átvételi folyamatot szervezetten, a lehető legkisebb veszteséggel kell lebonyolítani. A szerződéseket szakszerűen kell elkészíteni, különös tekintettel az együttmüködés operatív szabályait rögzítő Service Level Agreement-re. A szolgáltatónak pontos módszertannal kell rendelkeznie a feladatok lebontásához, a kapcsolódási pontok kiépítéséhez. A kockázatokat csökkenteni és menedzselni kell.

A folyamatosan bővülő tapasztalatoknak, az üzletre „rárepülő” tanácsadóknak és oktatási intézményeknek köszönhetően a kiszervezési módszertan folyamatosan fejlödött, jelentős részben szabványosodott, különböző programokon oktatott tananyaggá vált.

A kiszervezési piacnak, illetve azon belül az informatika és az üzleti folyamatok szektorának van alsó és felső szegmense. Az előbbiben találhatók az egyszerübb, ha úgy tetszik primitívebb tevékenységek, amelyek különösebb végzettség nélkül is könnyen elsajátíthatóak. Ilyen például az adatbevitel, a nyomtatott szövegek digitalizálása, az egyszerủbb honlapok tervezése, a telefonos ügyfélszolgálati munka jelentős része. A felső szegmensben bonyolultabb, nehezebben megtanulható, különleges szakértelmet igénylő munkafolyamatok vannak, mint például a termék- és a technológiai tervezés, piacelemzés vagy a pénzügyi tanácsadás.

A felső szegmens folyamatosan bővül, a palettán egyre komplexebb és igényesebb tevékenységek jelennek meg. Ezek közé tartozik például a kutatás és a fejlesztés, tehát a $\mathrm{K}+\mathrm{F}$ is.

\footnotetext{
${ }^{3}$ Magyarország például a német nyelvterület számára ", near-shoring" célterületnek számit, ahová reggel el lehet menni, és a munkanap végén vissza lehet jönni.
} 
A különböző felmérések ${ }^{4}$ jól mutatják, hogyan indult meg ez a tevékenységcsokor is egyes olcsó célországok felé. Az outsourcing sajátos formájának tekinthető az úgynevezett „gyógyászati turizmus" is, hiszen olyan országokban, mint például India, egy mütét elvégeztetése is sokkal olcsóbb, és ezzel a lehetőséggel egyre többen élnek. Hogy az egészségügynél maradjunk, a felső szegmens „krémjének” tekinthető a háromdimenziós röntgenképek (CT-k) szolgáltatásszerü elemzése: a digitalizált képeket üvegszálas kábeleken küldik át külföldi orvos-vállalkozóknak, a konzílium pedig többnyire internetes telefonon történik.

Ha az informatikai tevékenységek kiszervezéséről beszélünk, a piac alsó szektorát az egyszerűbb bérprogramozás jelenti, a felsőt pedig a komplex informatikai projektek menedzselése és a stratégiai szintü tanácsadás.

A szolgáltatói piac vezető vállalatainak jellemző stratégiája a piac felső szegmense felé történő mozgás, más szóval az „értékláncon való felfelé kapaszkodás”. Az alsó szegmensekhez tartozó egyszerübb tevékenységek könnyen szabványosodnak, tömegcikkesednek, a belépési korlátok pedig alacsonyak. Mindezek következtében alacsony szinten maradni, vagyis csak egyszerübb tevékenységeket felvállalni veszélyes pozíció: a heves verseny, a könnyü belépés, a tömegcikkesedés miatt az árak csökkennek, állandó a költségcsökkentési, racionalizálási kényszer, a megbízók a munkát könnyen átadhatják valaki másnak, aki kevesebbet kér. A felső hányad jóval biztonságosabb, oda kevesebbeknek sikerül eljutni, hiszen különleges tudásra, képességekre és tapasztalatokra kell szert tenni, megbízhatóságot sugárzó imágót kell építeni, legfelső szintű vezetőkkel kell személyes kapcsolatokat ápolni.

A felfelé kapaszkodás egy másik fontos megnyilvánulása az üzleti modellek bonyolultabbá válása. Az outsourcing piac vezető cégei globális hálózataiknak köszönhetően párhuzamosan tudnak az ügyfél telephelyén, valamint near-shoring és off-shoring formában dolgozni, attól függően, hogy az adott munka és az ügyfél mit kíván. A szolgáltató annál jobban jár, minél több tevékenységet tud alacsony költségszintű helyen elvégezni. A folyamatok különböző helyszínek közötti mozgatása nehéz feladat, de a költségelőnyök miatt megéri a fáradságot.

Az outsourcing szolgáltatói üzletbe egyre több ország és egyre több vállalat kapcsolódik be. Mivel a lehetőségek köre folyamatosan bővül, a megfelelö célállam és partner kiválasztása bonyolult feladat. A választást megkönnyítik a rendszeresen publikált országrangsorok ${ }^{5}$. Készítőik általában a 2 . sz. táblázatban látható tényezőket veszik számításba az egyes országok vonzerejének összehasonlításakor.

\footnotetext{
${ }^{4}$ Az Amerikai Egyesült Államokban tevékenykedő National Science Board Science and Engineering Indicators 2006 címü jelentésében átfogó és aktuális képet ad erröl a jelenségröl.

${ }^{5}$ Az A.T. Kearney stratégiai tanácsadó cég és a CIO informatikai magazin például minden évben publikálja a maga rangsorát.
} 


\section{Az outsourcing országrangsorok összeállításánál figyelembe vett tipikus tényezők}

\begin{tabular}{|c|c|}
\hline Pénzügyi (költség-) tényezők & $\begin{array}{l}\text { - Átlagbérek } \\
\text { - Bérek egyes szakmákban és munkakörökben } \\
\text { - Az infrastruktúra és a közszolgáltatások } \\
\text { - Uöltségei } \\
\text { - Atazási költségek } \\
\text { - Adók és adminisztrációs költségek } \\
\text { - Veruházási (pl. építési) költségek } \\
\end{array}$ \\
\hline A munkaerő mennyisége és minősége & $\begin{array}{l}\text { - Az adott szolgáltatói iparág mérete } \\
\text { - A minőségi rangsorokon elfoglalt hely, minőségi } \\
\text { bizonyítványok fajtái és elterjedtsége } \\
\text { - A megfelelő végzettségű munkaerő létszáma } \\
\text { - Az oktatási intézmények kibocsátó kapacitása, a } \\
\text { végzettek tudása } \\
\text { - A nyelvvizsgával rendelkezők száma, a } \\
\text { nyelvtudás minősége } \\
\text { - A munkanélküliségi ráta } \\
\text { - A munkavállalók alkupozíciója, fluktuáció }\end{array}$ \\
\hline Üzleti környezet & $\begin{array}{l}\text { - A befektetői országrangsorokon elfoglalt hely } \\
\text { - Bizalmi indexek } \\
\text { - Az infrastruktúra (úthálózat, internet, } \\
\text { telekommunikáció stb.) fejlettsége } \\
\text { - Kulturális különbségek és alkalmazkodási } \\
\text { készség } \\
\text { - A jogrend fejlettsége, a szellemi tulajdon } \\
\text { biztonsága } \\
\text { - Politikai kockázat, biztonság, terrorizmus } \\
\text { - Bünügyi statisztikák }\end{array}$ \\
\hline
\end{tabular}

A költségtényezők között - udvarias vagy kevésbé udvarias megfogalmazásokkal - rendszerint feltünnek a korrupció elterjedtségére, az „egy hivatalnokra vagy projektre eső átlagos megvesztegetési összeg" nagyságára vonatkozó mutatók is.

Egyes országoknál bizonyos mértékű szakosodás is megfigyelhető. Izrael például kiemelkedik a sorból kifinomult informatikai alkalmazások a biztonsági rendszerek fejlesztésében, Írország az úgynevezett „dobozolt” (márkázott, kereskedelmi forgalomba kerülő) szoftverek készítésében és a pénzügyi szolgáltatásokban jeleskedik, a balti országok leginkább a skandináv országokkal építik kapcsolataikat, India az utóbbi időkben nagyon sokat tette azért, hogy élre kerüljön a biotechnológiai iparban ${ }^{6}$, a szegényebb, fejletlenebb országok pedig a piac alsó szegmensére (adatbevitel, digitalizálás, telefonos ügyfélszolgálat) próbálnak koncentrálni.

\footnotetext{
${ }^{6}$ A Hyderabad városától nem messze található Genome Valley-ben számos biotechnológiai laboratórium és gyártóüzem található. Az itt tevékenykedő Bharat Biotech céget a William and Melinda Gates Foundation nemrég bízta meg egy malária elleni szer kifejlesztésével. India gyógyszeripara ma a negyedik legnagyobb a világon.
} 
Korábban már elmondtuk, hogy a termelési tevékenység kiszervezésében a ranglistákat ma egyértelmüen Kína vezeti. Ugyanilyen biztonsággal kijelenthetjük, hogy az IT outsourcing és a folyamatkiszervezés (BPO) területén India áll az élen: a piaci részesedését általában $80 \%$ körülire becsülik. Már a bevezetőben is jeleztük, hogy a konkrét számok e téren megbízhatatlanok, mégis, ha ránézünk az outsourcing-térképre, láthatjuk, hogy vannak (dollárban mérve) „milliárdos” és „milliomos” országok.

Az előbbiek közé tartozik Kanada és India. Kanada nyilvánvalóan az Egyesült Államok cégei számára megfelelő near-shoring célország: a költségelőnyök kicsik, de nincs nyelvi, szabályozási, kulturális probléma, a kockázat minimális.

A listavezető Indiát a nagy létszámú és jól képzett munkaerő, az angol nyelvtudás, az angol gyarmati múlthoz kapcsolódó kulturális örökség, a látványos költségelőnyök, a támogató állami politika és egy sor más tényező teszi vonzóvá (Bögel 2004). Az ország offshore szolgáltatási szektorában nagyon jól megfigyelhetők mindazok a törekvések és tendenciák, amelyekről fentebb szóltunk: a piac felső vége felé való kapaszkodás, az egyre komplexebb, igényesebb feladatok felvállalása, a helyszíni munka, a near-shoring és az off-shoring kombinálása, a globális kiszolgálás feltételeinek megteremtése.

A „milliomosok” táborában számos ország szerepel. Köztük van Magyarország is, a Cseh Köztársasággal, Lengyelországgal, valamint újabban egyre inkább Romániával és Bulgáriával versenyezve. Îrország számos kedvező tulajdonsága és képessége miatt hamar kiszervezési célországgá vált. Növekszik Spanyolország népszerüsége, nem csekély részben kellemes éghajlatának köszönhetően. Afrikában Egyiptomot és Dél-Afrikát lehet példaként megemlíteni, de már Ghánában is megjelentek az offshore szolgáltató cégek. Mexikó közelsége az Egyesült Államokhoz változatlanul nagy előny. Ázsia jó pár országa már régen ráharapott az IT outsourcing és a BPO üzletre.

A mezőny folyamatosan változik, az országok versenye éles. A CIO informatikai magazin 2006-os vonzerö-rangsora Magyarországot a „challenging” kategóriába sorolja, vagyis a „leading” címkével jelölt kör után rögtön a másodikba.

\section{Holnap}

Az utolsó részben a nemzetközivé vált outsourcing üzlet jövőjével, várható fejlődési trendjeivel és problémáival foglalkozunk.

Manapság szinte minden szakértői vélemény megegyezik abban, hogy további növekedés várható mind a keresleti (kiszervezői), mind a kínálati (szolgáltatói) oldalon. Mivel az outsourcingnak számos jól kimutatható előnye van, a fejlett országok vállalatai minden valószínűség szerint a jövőben is élnek ezzel a lehetőséggel. Nyugat-Európa fejlett országai és Japán csak nemrég csatlakoztak a trendhez. Mivel közben a szolgáltatói oldal is fejlödik, a kiszervezhető tevékenységek köre egyre bővül. Növekedés tehát lesz, ha nem is töretlenül harminc éven át, ahogy egyesek jósolják.

E pozitív jövőkép ellenére a fejlődés tele van problémákkal és kérdöjelekkel. A következőkben a teljesség igénye nélkül ezek közül sorolunk fel néhány fontosabbat. Ha stratégiai szemszögből vizsgáljuk őket, vannak olyan tényezők, amelyek lehetőséget, de olyanok is, amelyek veszélyt jelentenek.

$\mathrm{Az}$ elöző fejezetben már leírtuk, hogy az offshore szolgáltatások piacán jelenleg egyértelműen Indiáé a vezető poszt. A legfrissebb adatok és beszámolók alapján (lásd pl. 
Johnson-McGregor 2006) arra következtethetünk, hogy növekedése e téren munkaerő-korlátba ütközik: bár emberben nincs hiány, az oktatási rendszer csak nagyon nehezen tud lépést tartani az igényekkel. Indiának van néhány világszínvonalú műszaki egyeteme és üzleti iskolája, de ezek kibocsátása korlátozott és messze nem elegendő. Többféle becslést olvashatunk arról, hogy a friss diplomások mekkora hányada alkalmas arra, hogy színvonalasabb szolgáltató cégeknél dolgozzon: a számok 10-20\% között mozognak. A lakosságnak csak 70\%-a tud írni és olvasni. Nemrég egy felmérés során megállapították, hogy az általános iskolák első négy osztályát elvégzett tanulók 38\%-a nem tud értelmesen elolvasni egy bekezdésnyi szöveget, több mint fele pedig nem tud elvégezni nagyon egyszerü számtani müveleteket sem. A friss diplomások több mint 17\%-a munkanélküli, nagyjából 40\%-a pedig nem kap olyan munkát, amire a végzettsége elvileg alkalmassá tenné. Nem kap, mert a gyakorlatban a tudása kevésnek és alacsony színvonalúnak bizonyul.

Az indiai oktatási rendszer egy drága és szűk elitképzés és egy széles, alacsony színvonalú, forráshiányos tömegképzés kombinációja. Hogy ez jó-e így, arról élénk viták folynak. Manmohan Singh miniszterelnök szerint az ország képzési rendszere válságban van, és ez a válság veszélyes a gazdaság növekedésére nézve. A „talent pool” szemlátomást nem feneketlen. A szűk és lassan újratermelődő elitet felszívta a gazdasági fejlődés. Úgy tünik, vége annak az időszaknak, amikor könnyü volt egy olyan jól képzett mérnököt találni, aki boldogan dolgozott napi tízegynehány órát számunkra nevetségesnek látszó bérért. A munkaügyi alkupozíciók megváltozását jelzik a gyorsan növekvő fluktuációs mutatók is.

Az offshore outsourcing szolgáltatások iránt nagy a kereslet, de ezt a lehetőséget csak az képes kihasználni, aki a megfelelő mennyiségű és minőségű munkaerőt, a műszaki, gazdasági és nyelvi tudás szükséges elegyét produkálni tudja. A listavezető India kiütköző növekedési korlátai lehetőséget teremtenek más országok számára. A szomszédos Kína is rengeteg friss diplomást bocsát ki, de az általános színvonallal ott is problémák vannak: beszámolók szerint a mérnökképzés túlságosan elméleti jellegü, a végzősök nagy része nem rendelkezik értékelhető gyakorlati tapasztalattal, nem ért a problémamegoldáshoz és a csapatmunkához. Jó menedzserből különösen kevés van, ami abban is megnyilvánul, hogy a meglévőket nagyon gyorsan előléptetik és túlfizetik.

Mindezekből az is következik, hogy ha az offshore szolgáltatások területén a kereslet növekedésének trendje nem változik meg, India és Kína mellett másoknak is jut lehetőség.

Kérdés, hogy ezek kik lesznek, kik tudnak élni a felkínálkozó lehetőséggel. Az offshore-outsourcing piacon még számos alvó vagy éppen ébredező oroszlán, vagyis potenciális nagy játékos van. Oroszország és Ukrajna rengeteg jól képzett matematikussal, fizikussal és programozóval rendelkezik. Törökország kihasználhatja régóta meglévő vendégmunkási kapcsolatait Németországgal, már csak azért is, mert onnan nehéz szolgáltató tevékenységeket kiszervezni az angolul beszélő Indiába. Észak-Afrika volt gyarmatai francia vállalatok partnereivé válhatnak. Jelentősen nőhet Brazília és Argentína szerepe. A nyolcvanmilliós lélekszámú Vietnám képességeit és megbízhatóságát most „tesztelik” a nyugati országok és vállalatok. Egyes balkáni és balti államok szoftverexportja még nem érte el a kritikus nagyságot, de nagyon gyors tempóban növekszik.

Nyitott kérdés, hogy a szolgáltatói élvonalhoz tartozó országok vonzerejének megerösítésében és az „alvó oroszlánok” felébresztésében mekkora és milyen szerepet vállaljon az állam. Kétségtelen tény, hogy az élvonalbeli országok a sikereiket jelentős részben masszív állami támogatási programoknak, stratégiai akcióknak köszönhetik. Olyan országok, mint 
például Kína vagy Dél-Korea ${ }^{7}$, hatalmas összegeket fordítanak az oktatás és az infrastruktúra fejlesztésére, a K+F-re, a betelepülő cégeknek pedig rendkívüli kedvezményeket adnak. $\mathrm{Az}$ offshore-hullám meglovagolása több országban valóságos állami stratégiává vált, ami nem meglepő, hiszen rendkívüli lehetőségről van szó. A verseny tehát kétrétegü, államok és vállalatok között egyaránt folyik, sőt, harmadik rétegként megemlíthetjük a cégek szövetségeit, kamaráit is, amelyek közül egyesek (pl. az indiai NASSCOM) kifejezetten aktívak és eredményesek.

Az utóbbi időben annak is tanúi lehetünk, miként próbálják meg egyes államok az adórendszerük egyszerüsítésével, illetve az adók csökkentésével növelni az országuk vonzerejét, sajátos licitálós, könnyen veszélyessé váló játszmát folytatva egymással. Az államok feladata nem könnyü, a versenyképesség fenntartásához szükséges oktatási, kutatási, innovációs és termelési ökoszisztémák kiépítéséhez rendszerszemléletű gondolkodásra, gondos tervezésre és következetes végrehajtásra van szükség.

Az állam szerepének kérdése a másik, azaz a kiszervezői oldalon is felmerül. Mit kell tennie mondjuk az Egyesült Államok kormányának, ha azt tapasztalja, hogy a stratégiai iparágakból is egyre több munkahely vándorol olcsó országok felé? Jobb magára hagyni a piacot, vagy határozott állami beavatkozásra van szükség? Üzleti, politikai és akadémiai körökben élénk vita bontakozott ki arról, mennyiben érvényesek a mai világban a szabad versenyről és a szabad kereskedelemről korábban kialakult elképzelések - az, amit például Ricardo mondott a külkereskedelem szerepéről, megállja-e a helyét a mai feltételek közepette. Ebbe a lezáratlan eszmecserébe - aminek egy sor más tényező, így például a rekordösszegüre növekedett amerikai külkereskedelmi deficit vagy az amerikai polgárok és a központi költségvetés eladósodása is tápot ad -, olyan nagy nevek is beleszólnak, mint például Lester Thurow (2004) és Paul A. Samuelson (2004), vagy az üzleti világból Soros György (2006) és Warren Buffett.

Az országok közötti verseny fontos kérdése, hogy miként fog alakulni a két éllovas, India és Kína történelmi konfliktusokkal terhelt viszonya. A mai helyzetre a versengés és együttműködés egyaránt jellemző. Ha Kína továbbra is a gyártás átvételére, India pedig a szolgáltatásokra koncentrál, a két ország jól megférhet egymás mellett, kiegészítheti egymást. Kína azonban határozottan nyit a szolgáltatások felé is, Indiának pedig szüksége van gyártásra is, hiszen hatalmas lakosságának munkahelyeket kell teremtenie, a szolgáltató szektor nem tud mindenkit felszívni. A két ország üzletemberei mindenesetre élénk érdeklődést mutatnak egymás iránt: egyes indiai nagyvállalatok, mint például a Infosys és a Satyam sorra nyitják meg kirendeltségeiket Kínában, az ottani Huawei pedig az indiai szoftveripar fellegvárának számító Bangalore-ban toboroz szoftverfejlesztőket a termékeihez. A két ország irányítási és fejlődési modelljében sok különbség mutatkozik (a GDP-jükben például teljesen más a fogyasztás és a beruházás aránya; India demokrácia, Kína még nem az), így bizonyos értelemben ezek a modellek is versenyeznek egymással.

Feszültségek nemcsak országok között jelentkezhetnek, hanem országokon belül is. A tevékenységek kiszervezése a feltörekvő országokban kiváló lehetőséget ad azok felemelkedésére, akik megfelelő képzettséggel és képességekkel rendelkeznek. A jól jövedelmező vállalkozások, az offshore-üzlet óriásai, fejlett infrastruktúrával rendelkező szigetei a legmagasabb igényeket is kielégítő munkakörülményeket tudnak teremteni dolgozóiknak. A 
náluk dolgozók fizetése nyugati kollegáikéhoz mérve kicsi, de az adott országban rendkívül nagynak számíthat. Mindezek következtében nőnek a társadalmi különbségek, az alsóbb néprétegek pedig az olyan országokban, mint például India és egyes más ázsiai és afrikai államok, hatalmas tömegeket jelentenek.

A kiszervezés, különösen annak near-shoring és off-shoring változata, munkahelyek mozgását jelenti. Ez jó a fogadó régióknak és országoknak, de ahonnan a tevékenységek, az állások elvándorolnak, ott új, más munkahelyeket kell teremteni. A fejlett országokban sokáig tartotta magát az a nézet, hogy a termelés átadása az olcsóbb országoknak nem probléma, mert a jövő úgyis a szolgáltatásoké, a „K+F” koronagyémánt pedig a helyén marad. Napjainkban azonban ez az elképzelés egyre kevésbé állja meg a helyét, hiszen láthatjuk, milyen tempóban nő az offshore szolgáltatóipar, hogyan vesznek át egyre bonyolultabb, kifinomultabb szolgáltatásokat; megfigyelhetjük, hogyan erősödik egyes feltörekvő országok kutatási-fejlesztési tevékenysége, miként telepítik ki az olyan csúcstechnológiai cégek, mint például a Cisco vagy az IBM a fejlesztőközpontjaikat Indiába és más fogadó országokba.

Vita folyik arról is, hogy az innovációs (kutatás-fejlesztési) és a termelési folyamatot mennyire és milyen következményekkel lehet egymástól elválasztani, vagyis lényegében arról, kiszervezhetö-e a termelés egy másik országba úgy, hogy közben otthon a $\mathrm{K}+\mathrm{F}$ tartósan ütőképes marad, vagy aki a termelést kiadja a kezéből, az idővel innovációs képességeinek is búcsút mondhat, az ugyanis csak az előbbivel közvetlen és szoros kapcsolatban képes kiváló eredményeket produkálni.

Az outsourcing hatása a munkanélküliségre és a bérekre, a fiatal diplomások elhelyezkedési esélyeire, a demográfiai problémákra, a társadalmi egyenlőtlenségre még nyitott kérdés, egyelöre csak találgatjuk, hosszú távon milyen következményekkel kell számolnunk különböző országokban ${ }^{8}$. Kényes ügyről van szó, ami könnyen politikai problémává válik, és okkal vagy ok nélkül előidézője lehet a fokozódó idegenellenességnek. A kiszervezés mai formájában a globalizálódást erősíti, annak pedig hívei és ellenzői, barátai és ellenségei egyaránt vannak (Friedman 2005).

Nem látunk tisztábban abban a kérdésben sem, hogy milyen következményei lesznek a világgazdaságra és a világpolitikára vonatkozóan Kína és India gyors felemelkedésének. Különböző számítások és jóslatok látnak napvilágot arról, hogy ha a jelenlegi tempó tartós lesz, mennyi olajra, energiára, építőanyagra lesz szükség, mennyivel romlik a környezet állapota (lásd pl. Leeb 2006). Más oldalról viszont lelassulásuk, „kifulladásuk” világméretu” recessziót okozhat, hiszen jelenleg több fejlett ország exportját Kína növekvő étvágya húzza meg. Kínában nem is olyan régen adták el az első magánautót, ma pedig milliószám szaladgálnak a négykerekűek az utakon. Az outsourcing palettán mostanában megjelenő Vietnám a közelmúltban nőtte ki a „kerékpáros korszakot” és lépett át a „motorbiciklis” korszakba, ez után viszont, ha a fejlödés nem áll meg, az autók következnek, ehhez pedig acél és benzin kell. A források elhelyezkedése, az egyes országok kiszolgáltatottsága tekintetében jelentős szerkezeti átalakulásokat figyelhetünk meg, egyelöre beláthatatlan következményekkel.

\footnotetext{
${ }^{8}$ A munkanélküliségre gyakorolt hatásnál együttesen kell értékelni az outsourcing és a vele párhuzamosan megjelenő új típusú insourcing következményeit, az utóbbi alatt a betelepülö külföldi vállalatok tevékenységét értve. A globális kiszolgálás fentebb már leírt modelljéhez a fejlett országokban megnyitott irodák, leányvállalatok is hozzátartoznak. Az olyan nagy offshore-outsourcing cégeknek, mint például az indiai Wipro, számos kirendeltsége és fejlesztőközpontja van Nyugat-Európában és a fejlett világ más országaiban. Az USA-ban a külföldi vállalatok által toborzott alkalmazottak száma több millióra rúg.
} 
A kiszervezésnek, az outsourcing hullámnak a fentieken túl sokféle rejtett, nehezen megragadható és prognosztizálható társadalmi következménye is van, illetve lehet. A kiszervezés sajátos eleme annak a jelenségcsokornak, amit a „hagyományos gazdasági intézményrendszer bomlásának" nevezhetünk. E témával sokan, sokféle szempontból foglalkoznak. Egyikük, az MIT-n és a London School of Economics-on szociológiát tanító Richard Sennett szerint (Sennett 2006) mély intézményi változásoknak lehetünk tanúi, amelyek egyelőre a gazdaságnak abban a kis szeletében jelentkeznek erőteljesebben, amelyek az úgynevezett „új gazdaság” élvonalát képviselik, jelesül a csúcstechnológiai, a globális pénzügyi és az új típusú (globális és modern információs technológiára épülő) szolgáltatói szektorban. E szektor meglehetősen kicsi, de nagy a kulturális befolyása. A lényeg: a gazdaságban bomladoznak a régi, stabil, hierarchikus és bürokratikus, jórészt önellátó intézmények, a helyüket pedig mobil, változó, általában alkalmilag („projektekre”) összeálló szervezetek, "adhokráciák”, „,moduláris vállalatok”, „virtuális vállalatok” veszik át. A jelenség egyre határozottabban megfigyelhető az államigazgatásban is. E bomlás régóta tart, de az utóbbi időkben felgyorsult. A háttérben a technológia, leginkább az infokommunikációs technológia fejlődése és terjedése mozgatja az eseményeket.

A munkahelyek - írja Sennett - már nem lakható falvakra hasonlítanak, hanem vasútállomásokra, ahol csak rövid ideig tartózkodik az ember, aztán megy tovább. A régi intézményeknek ezer bajuk volt (lassúság, drágaság, bürokrácia stb.), viszont meg volt az az elönyük, hogy az emberek végig tudták gondolni a sorsukat. A „modern” szervezetekben nincs ilyen „személyes történet”, tagjaik alkalmi zsoldosokként csatlakoznak alkalmi társulásokhoz. Az intézményekkel együtt fragmentálódnak a hozzájuk kapcsolódó emberi sorsok is: vándormadarak keringenek mindenfelé, akik csak ideiglenesen raknak fészket itt-ott.

A modern moduláris-virtuális világ embere rövid távon gondolkodik, a potenciálját fejleszti és hangsúlyozza, nem sajnálva semmit. Nem lojális, már csak azért sem, mert hozzá sem lojálisak, legfeljebb alkalmilag. A probléma az, állítja Sennett, hogy az emberek általában nem ilyenek. A régi intézményi rendszer ezer helyen repedezik, és ennek következtében fokozatosan átértékelődnek olyan jelenségek és fogalmak is, mint a szakmai hozzáértés, a tehetség, a tapasztalat, az intézményi tudás, a lojalitás, a bizalom, a gondolkodás időtávja és így tovább. A hosszú távú következményeket illetően, hogy az emberek többsége jól érzi-e magát a kibontakozó új intézményi világában, csak találgatni lehet. Ezeket a kulturális és gondolkodásbeli változásokat nehéz megragadni és még nehezebb mérni, de közvetlen tapasztalatok, személyes beszélgetések alapján jól érzékelhetők.

Végezetül szóljunk néhány szót Magyarország helyéről és szerepéről is. Ha a legfrissebb vonzerö-rangsorokat nézzük, megállapíthatjuk, hogy a fontosabbakon az élvonalba tartozunk, a helyezésünk általában előkelő. Olyan fontos kiszervezési célországként tartanak számon bennünket, amely a near-shoring piacon jól kihasználhatja a fejlett európai országokhoz való közelségét és kulturális hasonlóságát, de az off-shoring piacon is fontos szerepet játszik.

A kedvező besorolás mellett azonban többnyire ott a figyelmeztetés: a mezőny változik, a pozíciónk hosszabb távon veszélyben van. A CIO magazin már említett rangsorában 2005-ben a második hely volt a mienk, de a szakértők prognózisa szerint pár év alatt akár húsz hellyel is hátracsúszhatunk. Mivel magyarázható ez a veszély? Az elemzők általában két dolgot említenek: az egyik a költségek növekedése, a másik a munkaerö-források kimerülése. Magyarország a kiszervezők szemszögéből drágul, a bérek emelkednek, a szolgáltató központokba pedig egyre nehezebb jól felkészült, nyelveken beszélő, a nyugati normákat 
és viselkedési mintákat ismerő embereket toborozni. Az oktatási rendszer nem tud lépést tartani az igényekkel.

Magyarország végigment azon a fejlődési úton, amit e cikk előző részeiben leírtunk. Gyártási tevékenységek átvétele után megindult a szolgáltató- és fejlesztőközpontok idevándorlása is. A különböző megnyilatkozásokból, tervekből azt is láthatjuk, hogy a kormány stratégiai szinten fontos szerepet szán a „hazánk mint Európa szolgáltató központja” jövőképnek. Kérdés, hogy mennyire sikerül ezt megvalósítani, milyen lesz a terv végrehajtása.

Az outsourcing versenyképességi rangsorokon, rögtön az élvonalbeliek után, fej fej mellett halad egy egész sor ország. Közvetlenül mellettünk ott van például a Cseh Köztársaság, Lengyelország, Románia, beindulhat Oroszország, Törökország, Horvátország. Ha a mezőny ennyire kiegyenlített, kis különbségeknek is nagy hatása lehet. A jelenlegi megszorító intézkedések ${ }^{9}$ jó része rövid távon kedvezőtlen a versenyképességünk szempontjából.

Milyen lehetőségeink vannak stratégiai időhorizonton? A költségek csökkentésére, nagyobb tömegü munkaerő bevonására még van lehetőség, ha például egyes vidéki egyetemek (pl. Debrecen, Miskolc, Szeged) köré sikerül jól működő oktatási-szolgáltatási-fejlesztési ökoszisztémákat kiépíteni. A költségközpontú versengés ugyanakkor hosszabb távon nem lehet cél, hiszen mindenkinek az lenne a jó, ha a hazai bérszínvonal egyre jobban közelítene a nyugat-európaihoz.

A másik út az értékláncon való felfelé kapaszkodás, az egyre bonyolultabb, igényesebb tevékenységek felé történő elmozdulás úgy, ahogy azt fentebb már leírtuk. Hazánk innovációs képességeiről, a K+F helyzetéről, a Tudományos Akadémiáról, a kutatók és az üzleti világ kapcsolatáról, az oktatási rendszer reformjáról szóló vitáinknak ${ }^{10}$ ez az egyik tétje.

\section{Hivatkozások}

Ante, S. - Hof, R. (2004): Look Who’s Going Offshore. Business Week, május 17., 84-85.

Bendor-Samuel, P. (2000): Turning Lead into Gold. Executive Excellence Publishing, New York.

Bőgel György (2004): Fehérgalléros kiszervezés: az offshore outsourcing jelensége. Competitio, december, 41-60.

Cairncross, F. (1997): The Death of Distance. Orion Business Books, London.

Daniels, J. - Radebaugh, L. (1993): International Business. Addison-Wesley, Reading.

Davies, P. (2004): What's This India Business? Nicholas Brealey, London.

Ewing, J. (2004): Is Siemens Still German? Business Week, május 17., 26-27.

Friedman, T. (2005): The World is Flat. Penguin Group, London.

Halvey, J. - Melby, B. (1997): Information Technology Outsourcing Transactions. John Wiley \& Sons, New York.

Hamm, S. (2004/b): To the Tech Giants Go the Spoils. Business Week, november 29. 32.

Johnson, J. - McGregor, R. (2006): Up to the Job? Financial Times, július 20., 11.

Klepper, R. - Jones, W. (1998): Outsourcing Information Technology, Systems and Services. Prentice Hall, Upper Saddle River, New Jersey.

Lacity, M. - Hirscheim, R. (1995): Beyond the Information Systems Outsourcing Bandwagon. John Wiley \& Sons, New York.

Leeb, S. (2006): The Coming Economic Collapse. Warner Business Books, New York.

Malone, T. (2004): The Future of Work. Harvard Business School Press, Boston.

${ }^{9}$ A cikk 2006 augusztusában készült.

10 Lásd erröl például az Élet és Irodalomban és a Népszabadságban 2006 tavasza óta megjelent cikkeket és kommentárokat. 
Matlack, C. et al. (2004): Job Exports: Europe’s Turn. Business Week, április 19. 20-21.

Moore, G. (2002): Crossing the Chasm. Harper Business, New York.

Prestowitz, C. (2005): Three Billion New Capitalists. Basic Books, New York.

Robinson, M. - Kalakota, R. (2004): Offshore Outsourcing. Mivar Press, Inc. Alpharetta.

Samuelson, P. (2004): Where Ricardo and Mill Rebut and Confirm Arguments of Mainstream Economists

Supporting Globalization. Journal of Economic Perspectives, 2004. nyár, 135-146.

Sennett, R. (2006): The Culture of the New Capitalism. Yale University Press, New Haven.

Soros, G. (2006): The Age of Fallibility. PublicAffairs, New York.

Sull, D.: Made in China. Harvard Business School Press, Boston.

Targowski, A. - Korth, C. (2003): China or NAFTA: The World's Largest Market in the Twenty-first

Century. Advances in Competitiveness Research, 2003. november 1.

The Economist (2004/a): A World of Work. November 13.: 3-5. (melléklet)

The Economist (2004/b): Out of Captivity. November 13. 70.

The Economist (2004/c): Men and Machines. November 13. 6. (melléklet)

Thurow, L. (2004): Do Only Economic Illiterates Argue That Trade Can Destroy Jobs and Lower America's

National Income? Social Research: The Worldly Philosopers at Fifty, március

Zakaria, F. (2004): Rejecting the Next Bill Gates. Newsweek, november 29., 21. 